\title{
SOCIAL JUSTICE IN THE DIGITAL WORLD: 21ST CENTURY EXPLORATIONS IN TECHNOLOGY POLICY
}

\author{
Adhiraj Kapuria \\ Pathways School Gurgaon \\ DOI: 10.46609/IJSSER.2020.v05i08.019 URL: https://doi.org/10.46609/IJSSER.2020.v05i08.019
}

\begin{abstract}
Technological advancements in the 21 st century have started to revolutionize the functioning of our society and economy. Historically technological advancements have been perceived positively, with businesses being given the free-hand to develop new technologies that fast track production processes and enhance economic activity. However, recent developments in artificial intelligence, robotics, machine learning, and cloud computing have adversely affected employment rates and income equality, whilst also posing a threat to democratic processes, and the social fabric that ties diverse communities together. The worst consequences of these changes are faced by marginalized groups and low-income communities. This paper has explored the need to regulate and guide technological innovations through policy interventions that seek to ensure that technological advancements do not come at the cost of equality and social justice, and aid the state in promoting public welfare. This paper has examined the positive and negative applications of technology policy over the past few decades. Lastly, the paper concludes that the creation of checks and balance mechanisms within the state structure is imperative to ensure inclusive and holistic development through public policy interventions.
\end{abstract}

Keywords: Social Justice, Policy, Welfare, Employment, Technology

\section{Introduction}

The progression of human civilization is often determined by how we adapt to changes in our external environment. Overcoming challenges, some of which are a product of human activity and innovation is integral to our survival and prosperity as a species. One of the biggest changes in our external environment over the past century is the rapid rate of technological developments and advancements. Renowned policy advisor Lewis M. Branscomb defines technology as "the aggregation of capabilities, facilities, skills, knowledge, and organization required to successfully create a useful service or product" (Branscomb, 1995). This definition of technology is broad, and successfully includes inventions that were ahead of its time, including artificial intelligence, 


\section{International Journal of Social Science and Economic Research}

ISSN: $2455-8834$

Volume:05, Issue:08 "August 2020"

bionics, and android robots. Some of these technological advancements have changed the way our society, and economy functions. Whilst it has enhanced the general standard of living across the world, it has also led to the concentration of wealth in the hands of the few, and the weakening of our democratic and public institutions. It, therefore, becomes important for society to control technology, and advancements within it to ensure that it develops in a way that is consistent with our moral compass and conducive to our social fabric. Technology policy is defined as the means through which society and state nurtures and regulates technological advancements and optimizes technological applications in the service of common goals and interests (Dodgson \& Bessant, 1997)

Technological policy has been conceptualized as a form of active industrial policy that seeks to protect society from instances of market failure. It is argued that markets deciding industrial development pathways, in the long run, leads to underinvestment in research and development in competitive oligopolistic markets, creation of monopoly trends, and misallocation of resources and means of production that are eventually used to undermine public and social good (Borris \& Stowsky, 1997). This becomes important particularly in the populist and polarized political climate of the twenty-first century. Cyber attacks preceding elections by foreign powers, formulation of high-end surveillance programs by populist governments, and even the high rates of online crimes against minors demand the formulation and implementation of a comprehensive technological policy (Andersen \& Rainie, 2020). Hence there is a need to collect empirical evidence on technology development and implementation from different economies, societies, time periods, and geographical regions to develop state instrumentalities that correct market and social failures (Borris \& Stowsky, 1997).

Technology policy in the 21 st century covers the applications of artificial intelligence and robotics, development and usage of surveillance systems by governments and private actors, accessibility to different networks as well as different layers of the internet, regulations surrounding automation of business processes, and self-driving cars. The accelerating pace of technology has transformed old markets and created new ones, which governments often choose to regulate (Branscomb, 1992). Formulating a technology policy also helps governments regulate and control economic growth and activity in a way that allows domestic businesses to use resources sustainably, and gain a competitive advantage in trade over rival countries. It also allows us to define our relationship with each other and the state. There is an obvious trade-off between privacy and security, and wide-scale surveillance applications (such as those used in China) ensure protection against cyber or physical attacks, from internal or external aggressors by compromising each individual's right to privacy and even autonomy (Andersen \& Rainie, 2020). Technology policy has thus become a divisive factor in political discourse and strengthened the age-old liberal-conservative divide, with one side advocating for a free market, 


\section{International Journal of Social Science and Economic Research}

ISSN: $2455-8834$

Volume:05, Issue:08 "August 2020"

fewer regulations and lack of state control over data, and the other arguing for public regulation of technology-driven markets, and data for the larger good (Zetter, 2018). The impact of technology on our society and the economy is explicit, permanent, and visible. It is important to study and evaluate governments' responses (or their absence) to novel technological innovations of the 21 st century to develop a comprehensive path to sustainable and inclusive development.

\section{Background}

Thorstein Veblen, an American economist, and sociologist theorized on technological determinism, which presumes that the technology at the disposal of society drives the development of its social structure and cultural values (Smith \& Marx, 1994). However, the first major description of a technologically deterministic view of socio-economic development was put forward by the German sociologist, Karl Marx. Karl Marx envisioned the creation of an egalitarian society that was led by a dictatorship of the proletariat. He emphasized on the fact that changes in production technology that influence peoples' means to produce commodities ultimately affect interpersonal and social relations, organizational and state structures, and even socio-cultural practices (Bimber 1990). Towards the end of the second world war, technology policy in the United States was primarily aimed at incentivizing innovation by funding capital requirements and developing intellectual infrastructure for research, providing tax incentives to corporations who intensely invest in research \& development, and providing direct and indirect assistance to private and public research entities (Bush, 1945). The cold war further promoted research and development in the scientific and technological arena, with inventions serving the dual purpose of making lives convenient and generating economic prosperity, whilst also competing with and attempting to undermine Soviet Scientific progression.

Marx's perspective on technological determinism and the impact of technology on society has been most evident in the 21 st century, since the industrial revolution. Technology has impacted taxation systems, communication, trade, political processes, international relations, and socioeconomic development in all societies irrespective of differences in historical background and resource availability. The emergence of robotics and artificial intelligence (AI), which have given automation a new dimension has fundamentally reshaped not only business processes but also the economy and society. The impact that technology has had on our lives has also changed perceptions around technological developments. Concerns around the emergence of new technologies include loss of income and employment opportunities for low-skilled and lowincome workers and the widening of socio-economic inequality within and beyond national borders (Acemoglu \& Restrepo, 2018). Moreover, artificial intelligence systems gaining cognitive skills and sentience could also lead to the loss of innocent lives beyond causing widespread unemployment. Concerns extend to slowing the growth of AI, in order to prevent it from overtaking human beings as the dominant force of planet Earth, with many experts 


\section{International Journal of Social Science and Economic Research}

ISSN: $2455-8834$

Volume:05, Issue:08 "August 2020"

suggesting that AI could potentially see its creator, humanity as a rival, and seek to eliminate it altogether (Piper, 2018). Even though some of these concerns are fairly extreme, the literature suggests that technological advancements can have effects opposite to what is theorized in technological determinism, and contribute to the destruction, and not the prosperity of society.

This has prompted a shift in the perception and public policy surrounding technology. Instead of solely promoting and incentivizing research and development, policies and legislation now seek to regulate and control such research, to prevent it from having a detrimental impact on our communities (Piper, 2018). Self-Driving cars, for example, are extensively regulated in the United States by the government-controlled National Transportation Safety Board. Policy aimed at regulating self-driving cars specifically was formulated first when self-driving cars marketed by Uber failed to distinguish between jaywalkers and other nearby objects, hence putting human lives at risk (Beene, 2019). Since then, companies testing autonomous vehicles have been put through strict regulatory procedures to ensure that general safety protocols are adhered to.

\section{Discussion}

Technology policy seeks to promote, regulate, or supplement innovations in the field of communications, artificial intelligence, use of surveillance and robotics, and so on. 'Net Neutrality' has become an important part of political discourse in the past few years in India and the United States. Concerns surrounding this area were first raised in the early 2000s when companies like Comcast and AT\&T started to block users' access to certain web pages and virtual private networks (Finley, 2020). Barriers to accessing information hamper innovation, and advancements in the long-term, which prompted the Federal Communications Commission (to issue regulations that restricted providers from disallowing users to access legal content on the internet, and from preventing individuals from connecting to any internet connection of their choice, including Wi-Fi and virtual private networks (Finley, 2020). Designating content online as legal or illegal also falls in the ambit of technology policy. This is often used to prevent the spread of morally objectionable content, but governments have often used it to forward their ideology and agenda. Subsequent internet bans in disturbed and conflict-ridden regions in Kashmir, and the North-East by the right-wing nationalist government in India through its technology policy has widely been criticized by social, and internet activists (Varadarajan, 2020). Similar methods of suppressing civil dissent in the face of mass protests have been adopted by the government of Iran at the national level (Newman, 2019). Government surveillance, and the trade-off between security and privacy that it represents, has become one of the most crucial political clashes of the 21 st century. Whilst proponents of implementing mass surveillance systems that can allow governments to access individuals' private messages, tap phone calls and movements without specific warrants claim that it benefits national security, and reduces the crime rate, critics claim that these systems give governments, who are often 


\section{International Journal of Social Science and Economic Research}

ISSN: $2455-8834$

Volume:05, Issue:08 "August 2020"

authoritarian, the ability to suppress dissent and inhibit the freedom and privacy of their citizens (E.F.F, 2019). Chinese companies are required to hand over any data of their customers to the government at a moment's notice. The technology policy of India allows the government of intercept communications and establishes checks and balances to prevent misuse. However, the ambiguity around surveillance laws in India has prevented these mechanisms to adequately check the actions of the government over the past few years (C.I.S, 2016). The U.S. Government is also allowed to monitor sensitive and private information of individuals without probable cause, irrespective of their nationalities by means of a FISA court order (A.C.L.U., 2019).

The growing usage of machine learning artificial intelligence and robotics over the past few years in industry and business threatens to create widespread employment of unskilled workers. Even though job creation in certain sectors has increased due to automation, the part of the workforce that faces the worst unemployment crisis is usually considered to be ineligible for employment in the 'knowledge-oriented sectors of the economy', which includes personal/health care, luxury goods sectors, and the service sector (Vermeulen, et. al., 2018). This necessitates policy-interventions by the government which often take the form of robot tax. Robot taxes are levied on companies that replace workers with robots with an intention to earn higher profits. It serves the dual purpose of dissenting replacement of workers and paying for the public safety net for displaced workers, who usually belong to low-income and socially vulnerable communities (Thompson, 2018). Robot taxes are widely debated, as critics claim that they hamper innovation, competition, and productivity, and have a detrimental effect on the standard of living of society in the long term (Marvala, 2018). Moreover, automation has gradually occurred since the first industrial revolution at varying rates across the world, and newer developments in AI and robotics are not an exceptional change, but a part of expected linear technological advancement (Dunlop, 2017). Proponents claim that the unemployment threats unskilled labourers are expected to face in the coming years are unprecedented, which necessitates the strengthening of social security systems, including universal basic income, and free education and healthcare. Robot taxes put the burden of welfare on business owners, who benefit most out of automation, given its positive impact on profits (Osborne, 2017). With respect to the compounding of automation, policymakers are not just concerned about the spike in unemployment rates, but also the widening of socio-economic equalities, which aggravates the risk of civil disturbances and class conflict and hampers the social fabric of a country. Beyond social security, policyinterventions that can enable a smooth and equitable transition to a completely automated world include strengthening of labour unions and implementing dynamic skill and refresher training programs (Romero, 2018). 


\section{International Journal of Social Science and Economic Research}

ISSN: $2455-8834$

Volume:05, Issue:08 "August 2020"

\section{Conclusion}

Technology policy has rightly become a crucial part of political discourse across the world in the 21 st century. Data protection, manipulation, and distribution have come into the limelight over the past few years, partly because of the recent attacks on electoral and democratic processes of the European Union and the United States by foreign hackers (Granville, 2018). Businesses have access to significant amounts of sensitive data belonging to their customers. These have been sold or handed over to authoritarian governments, foreign adversaries, and other third-party actors. This blatant breach of privacy has prompted foreign governments to enact data privacy acts that seek to restrict unethical data practices of corporates (Farigram \& Ingram, 2019). Technology affects the society and economy in different ways, and being prepared for such disruptions is beneficial for maintaining security, autonomy, and social equality and justice. There is a need to emphasize and implement programs that seek to increase public awareness about sensitive issues in technology through policy.

It is imperative for public authorities to develop comprehensive technology policies to promote social welfare. However, they have also been used by states to promote economic inequality, social injustice, and prevent people from actualizing their civil liberties and fundamental human rights(Varadarajan, 2020). Technology policy hence is similar to other instrumentalities of the state that is prone to misuse. The ratifications of this fallacy lie in establishing a checks and balances mechanism by empowering independent public institutions. Legal review of policy, right to information mechanisms, parliamentary committees, and civil society organizations can be used to review technology policies and legislations to ensure that they are directed at promoting public and social welfare. As technology becomes smarter, the need for managing and developing it in a way that ensures inclusive development through public policy interventions becomes more urgent and pressing.

\section{References}

Acemoglu, D., and Restrepo, P. (2018). Robots and Jobs: Evidence from US Labor Markets.

American Civil Liberties Union (2019). Documents Confirm how the NSA's Surveillance Procedures Threaten American's Privacy.

Andersen, J. and Rainie, L. (2020). Concerns about democracy in the digital age. Pew Research Center

Beene, R. Fatal Self-Driving Uber Crash Prompts Call for Tighter Oversight. Yahoo Finance. 19th November 2019 
International Journal of Social Science and Economic Research

ISSN: 2455-8834

Volume:05, Issue:08 "August 2020"

Bimber, B. (1990). Karl Marx and the Three Faces of Technological Determinism Social Studies of Science

Borris, M. and Stowsky, J. (1997). Technology Policy and Economic Growth. UC Berkeley: Berkeley Roundtable on the International Economy

Branscomb, L. M. (1995). Confessions of a Technophile. Springer Science \& Business Media.

Branscomb, L.M. (1992). Why America Needs a Technology Policy. Harvard Business Review

Bush, V. (1945). Science The Endless Frontier. United States Government Printing Office

Center for Internet and Society. (2016). State of Surveillance in India.

Dodgson, M., and Bessant, J. (1997). Effective innovation policy: A new approach. Long Range Planning

Dunlop, T. What is a robot exactly and how do we make it pay tax. The Guardian. 12th March 2017

Electronic Frontier Foundation. (2019). Surveillance Technologies.

Farivar, C., and Ingram, D. California is bringing law and order to big data. It could change the internet in the U.S. NBC News. 13th May 2019

Finley, K. The WIRED Guide to Net Neutrality. Wired. 5th May 2020

Granville, K. Facebook and Cambridge Analytica: What You Need to Know as Fallout Widens. The New York Times. 19th March 2018

Marwala, T. (2018). On Robot Revolution and Taxation. Cornell University

Oberson, X. (2017). Taxing Robots? From the Emergence of an Electronic Ability to Pay to a Tax on Robots or the Use of Robots. World Tax Journal.

Piper, K. Why Elon Musk fears artificial intelligence.Vox 2nd November 2018

Romero, S. Wielding Rocks and Knives, Arizonans Attack Self-Driving Cars. The New York

Times, 31st December 2018

Smith, M.R. and Marx, L. (1994). Does Technology Drive History? The Dilemma of Technological Determinism. The MIT Press

Thompson, D. A World Without Work. The Atlantic. 14th March 2018 
International Journal of Social Science and Economic Research

ISSN: 2455-8834

Volume:05, Issue:08 "August 2020"

Varadarajan, S. Modi's Thought Control Firewall in Kashmir May Be the Internet's Future in India. The Wire. 19th January 2020

Vermeulen, B. Kesselhut, J., Pyka, J., Saviotti, P.P. The Impact of Automation on Employment:

Just the Usual Structural Change? Sustainability

Zetter, K. The Crisis of Election Security. The New York Times. 26th September 2018 